\title{
Fertilization Studies and Assisted Fertilization in Mammals: Their Development and Future
}

\author{
Ryuzo YANAGIMACHI ${ }^{1)}$ \\ 1) Department of Anatomy, Biochemistry and Physiology, Institute for Biogenesis Research, University of Hawaii Medical \\ School, Honolulu, Hawaii 96822, USA
}

\begin{abstract}
Studies of mammalian fertilization progressed very slowly in the beginning because of difficulties in obtaining a large quantity of fully mature eggs at one time. With progression of techniques to collect and handle eggs and spermatozoa, research in mammalian fertilization advanced rapidly. Today, far more papers are published on mammalian gametes and fertilization than those of all other animals combined. The development of assisted fertilization and related technologies revolutionized basic research as well as human reproductive medicine and animal husbandry. Reproduction is fundamental to human and animal lives. The author lists a few subjects of his personal interest for further development of basic and applied research of gametes and fertilization. Each reader will probably have more exciting subjects of future investigation.
\end{abstract}

Key words: Assisted fertilization, Egg, Fertilization, ICSI, Sperm

(J. Reprod. Dev. 58: 25-32, 2012)

\section{Discovery of Mammalian Eggs, Spermatozoa and Fertilization}

A 1though it was known from ancient times that the eggs of birds and frogs were the start of new life, no one was certain whether this was true for mammals until Karl von Bare ${ }^{1792-1876}(1827)$ discovered tiny eggs within dog and human ovaries. Interestingly, spermatozoa had been discovered 150 years earlier by Anton van Leeuwenhoek $^{1632-1723}(\sim 1676) *$ and a medical student of Leiden, Johan Ham who saw many tiny tadpole-like creatures ("animacules") within human seminal plasma. Leewenhoek later saw same creatures in the semen of the rabbit, dog and fish. He thought that they were normal components of semen originating from the testis. Obviously, Leeuwenhoek saw spermatozoa without knowing their exact biological role. It was not until 1840s-1870s when it became clear that spermatozoa and eggs of all animals, large or small, are cells [Albert von Koelliker ${ }^{1817-1905}$ (1840) ; Karl Gegenbaur ${ }^{1826-1903}$ (1861)] and that sperm entry into the egg - in particular the union of sperm and egg nuclei (sygamy) - is the essence of fertilization and provides cytological evidence of biparental inheritance [Edouard van Beneden ${ }^{1846-1910}$ (1875); Oscar Hertwig ${ }^{1849-1922}$ (1876); Herman Fol $\left.^{1845-1892}(1879)\right]$.

\section{Studies of Mammalian Fertilization}

The analysis of animal fertilization began from the start of the $20^{\text {th }}$ century. Because invertebrate animals such as sea urchins and starfish produce millions of mature eggs at one time and their

Received: October 26, 2011

Accepted: November 1, 2011

(C)2012 by the Society for Reproduction and Development

Correspondence: R Yanagimachi (e-mail: yana@hawaii.edu) fertilization and embryo development can be followed readily in a dish of seawater, most of the early and important investigations of fertilization were done using gametes of aquatic invertebrate animals. In mammals, even after induction of superovulation, only a few eggs (usually up to 40-50) can be obtained from a single female. Furthermore, eggs are normally fertilized and develop within the female's body, which makes observations and experiments of eggs cumbersome. Because most investigators of mammalian eggs and fertilization used fixed and stained materials, the study of mammalian fertilization progressed very slowly. It was Colin "Bunny" Austin who disclosed many details of mammalian fertilization using the newly developed phase-contrast microscope that allowed spectacular imaging of living cells without staining (for review, see Austin [2]). Studies of mammalian gametes and fertilization studies were boosted by the discovery that mammalian spermatozoa need to be "capacitated" to become fertilization competent [3-5]. The use of electron microscopy (since 1950s) and development of the techniques that allowed in vitro fertilization (IVF) of eggs and in vitro culture of fertilized eggs (since 1960s) accelerated the progress of fertilization studies in mammals. With the advent of new technologies, such as micro-biochemical, molecular biological, and gene manipulation technologies, the progress of mammalian gametes and fertilization research became even faster (for reviews, see Table 1). Today, the number of papers dealing with mammalian fertilization (including humans) far exceeds that of papers reporting fertilization in all other animals combined. Nevertheless, many important questions concerning mammalian fertilization remain unanswered as follows. (a) Does the temporal sperm storage in the oviduct isthmus occur in all animals including primates and human before in vivo fertilization? (b) Is phagocytosis of "surplus" spermatozoa by the epithelium of female genital tract just for "cleaning" of the tract or something else? (c) Do mammalian eggs, follicular fluid components in the oviduct ampulla or the 
Table 1. Recommended reviews [refs.] of mammalian gamete and fertilization

\begin{tabular}{ll}
\hline Subjects & \\
\hline General biology of spermatozoa [6-8] & Fertilization in general [2, 15-17, 24-29] \\
General biology of eggs [2, 9] & Sperm-cumulus interaction [30, 31] \\
Sperm maturation in epididymis [10-12] & Sperm-zona interaction [32-35] \\
Sperm transport in female tract [13, 14] & Sperm-egg fusion [17, 36, 37] \\
Sperm capacitation [15-19] & Egg activation [38, 39] \\
Sperm acrosome reaction [20-23] & Centrosome and syngamy [40, 41] \\
\hline
\end{tabular}

Table 2. References which report the first birth of normal offspring after IVF and ICSI

\begin{tabular}{lcc}
\hline Species & IVF (year) & ICSI (year) \\
\hline Rabbit & $46(1959)$ & $63(1989)$ \\
Mouse & $66(1970)$ & $78(1995)$ \\
Rat & $67(1974)$ & $79(2000)$ \\
Hamster & $68(1992)$ & $80(2002)$ \\
Cat & $69(1988)$ & $81(1998)$ \\
Horse & $70(1991)$ & $82(1998)$ \\
Cattle & $71(1982)$ & $64(1990)$ \\
Pig & $72(1988)$ & $83(2000)$ \\
Sheep & $73(1987)$ & $84(1996)$ \\
Goat & $74(1985)$ & $85(2003)$ \\
Human & $55(1978)$ & $65(1992)$ \\
Baboon & $75(1984)$ & $86(2010)$ \\
Rhesus Monkey & $76(1984)$ & $87(2002)$ \\
Cynomol. Monkey & $77(1984)$ & $88(2002)$ \\
\hline
\end{tabular}

* Leeuwenhoek was an unlikely scientist. He was a fabric merchant who lived in Deft, Holland. He received no higher education. As a young man he was interested in a glass magnifier to examine the quality of cloth. In 1665, Robert Hooke's illustrated book "Micrographia" had been published. Being impressed by many beautiful drawings in the book (flea, sections of cork and etc), Leeuwenhoek started to make a single lens microscope (magnifier) using his spare time. What Leeuwenhoek and many others found was that the smaller the lens and greater the radius of curvature, the greater the magnification. Judging from the details of his drawings, some of Leeuwenhoek's microscopes must have had a magnification of up to 400-500 times with a maximum resolution of nearly 1 $\mu \mathrm{m}$. He examined almost everything he could put under his microscope. His superb drawings (e.g., bee's mouthparts and sting and thin sections of animal and plant tissues) impressed his shop's customer Regnier de Graaf ${ }^{1641-1673}$, a physician and anatomist, who was a young member of the Royal Society of London. He wrote a letter about Leeuwenhoek to the Secretary of the Society. Starting from 1673, Leeuwenhoek's random illustrations with notes in conversational style were translated into Latin (scientific language of the time) and published as letters in the Society's official journal, Philosophical Transactions of the Royal Society of London. During next 50 years he sent 560 letters to the Society. He was secretive about lens making and never gave his microscopes to others while he was alive. Leeuwenhoek was the first to discover protozoa in pond water (1674), bacteria in mouth (1676), spermatozoa (1677), muscle fiber (1682) among many others. His insatiable curiosity, extraordinary tenacity and skill are remarkable. His caution not confusing the facts with his speculation is admirable. Leeuwenhoek was elected as a member of the Royal Society of London in 1680, but he never visited the Society as its member. For more interesting stories about him, readers are referred to internet and a book by Ford [1] . cumulus oophorus really attract spermatozoa "chemotactically"? (d) Is it possible to shorten or even bypass capacitation so that epididymal or ejaculated spermatozoa could fertilize cumulus- and zona pellucida-intact eggs without any delay after insemination? (e) What is/are the natural trigger(s) of sperm acrosome reaction: oviduct fluid, cumulus or zona pellucida? (f) Do spermatozoa pass through the cumulus oophorus and zona pellucida purely mechanically or aided by lytic substances including enzymes? (g) Why spermatozoa cannot go from the inside out of the zona pellucida? (h) Is phospholipase C-zeta in spermatozoa the real or the sole sperm-born egg-activating factor? (i) Do unfertilized eggs, zygotes and preimplantation embryos, and even spermatozoa in the oviduct send some sort of chemical "messages" to the mother?

\section{In Vitro Fertilization (IVF): History and Today}

Pioneer researchers considered IVF not only as a power tool for analytical studies of fertilization processes, but also as a means of facilitating animal reproduction and overcoming female infertility caused - for example - by oviduct occlusion or disease. Attempts to fertilize mammalian eggs in vitro go back to $1870 \mathrm{~s}$ when Schenk [42] first reported cleavage of guinea pig eggs after in vitro insemination using epididymal spermatozoa. Although Pincus and Enzmann [43] and Venge [44] reported the birth of IVFgenerated rabbit pups, it was not until 1954 when Thibault et al. [45] and Chang [46] presented unequivocal evidence of successful IVF, again using the rabbit. The use of "capacitated" spermatozoa collected from the uterus of mated females was the key to their success (for early history of IVF, see Austin [2]; Chang [47]). Table 2 lists the years when first IVF and intracytoplasmic sperm injection (ICSI) offspring were obtained in mammals including the human. Mammalian IVF was first achieved in the rabbit; the trick was to use in vivo "capacitated" spermatozoa, not epididymal or ejaculated spermatozoa [46]. In fact, in vitro capacitation of ejaculated rabbit spermatozoa was difficult until Brackett and Oliphant [47] found that $5 \mathrm{~min}$ of treatment with a hypertonic medium (380 mOsmol) prior to incubation in isotonic medium (305 mOsmol) capacitate them fairly well. More efficient rabbit sperm capacitation was achieved by Zeng et al. [48] who added excess (10 mM) $\mathrm{NaHCO}_{3}$ to each of the hypertonic and isotonic media. We often hear that sperm capacitation and IVF in some animals are very difficult or impossible. It is we who do not know the tricks. For example, we should remember that human IVF used to be very difficult and now is one of the easiest to achieve.

As we know there is no single medium that supports sperm 
capacitation and fertilization in all species of mammals. A medium which is excellent for IVF of one species is often not at all suitable for IVF for other species, even if they are closely related. The internal milieu (fluid) in the female genital tract of one species must have evolved independently from that in all other species. An interesting example is the IVF medium for the golden hamster. Spermatozoa of this species require a low concentration of neurotransmitters such as taurine, hypotaurine and epinephrine (all with antioxidant activities) in the medium for their survival and capacitation [49-51]. Human and bovine spermatozoa, unlike hamster spermatozoa, do not need such substances for their survival. They already contain at least taurine and hypotaurine [52]. Apparently, golden hamster spermatozoa do not contain such substances or even if they do, they cannot retain these intracellularly or require them in the medium.

\section{Human IVF}

The claims of successful human IVF by early pioneers (e.g. [53, 54]) was not convincing. The "cleavages" of eggs that these researchers considered as evidence of fertilization could be fragmentation of degenerating eggs [2]. It was in the 1960s when several researchers and their teams began to work on human IVF: P. Steptoe ${ }^{1913-1988}$ and R. Edwards ${ }^{1926-}$ in England, M. Hayashi ${ }^{1913-1977}$ in Japan, P. Soupart ${ }^{1923-1981}$ and H. Jones ${ }^{1910-}$ in the United States, and A. Lopata $^{1939-}$ in Australia among few others. Steptoe and Edwards [55] were the first to produce an IVF baby after more than 100 unsuccessful attempts. This baby developed from an egg matured in vivo and fertilized in vitro. Subsequent technical improvements of IVF by Edwards' team and others were rapid [56, 57]. In 1980, about $80 \%$ of assisted fertilization was performed in university hospitals. Today over $80 \%$ of assisted fertilization is performed in private clinics. Bob Edwards' receipt of the 2011 Nobel Prize in Medicine was a real delight to all of us who engage in reproduction research and work in fertility clinics. One should be aware that Edwards (Ph.D) started his career as a basic reproductive biologist, collaborated with Steptoe (MD), and overcame all sorts of difficulties including resistance and criticisms from both scientific and non-scientific communities during the entire course of his endeavor. For the story behind his success, readers are referred to a memoir written by Edwards himself [58].

\section{Intracytoplasmic Sperm Injection (ICSI)}

The first injection of spermatozoa into mammalian eggs was done by Uehara and Yanagimachi [59]. This used the golden hamster, whose eggs well tolerate a small puncture of the plasma membrane. We started this experiment from simple curiosity. Testicular spermatozoa are known to be incapable of fertilizing eggs under normal conditions. They are barely motile even though their nuclei have completed the meiosis. We wonder what would happen if we injected a sperm head (nucleus) into an egg? Would the egg start to develop? Even if it does not, it is interesting to know. When we reported that hamster sperm nuclei (from epididymis and testis) and even freeze-dried human sperm nuclei are capable of decondense and transform into fully developed pronuclei, our papers $[59,60]$ were largely ignored by others except for a few who used the ICSI technique for analysis of the interactions between sperm nucleus and egg cytoplasm (e.g., [61, 62]).

The first ICSI babies were born using the rabbit [63] followed by the cow [64]. The birth of the first human ICSI babies was reported by Palermo et al. [65]. Table 2 lists the years when the first ICSI (and IVF) offspring were obtained in various species. For the history of animal and human ICSI, readers are referred to Yanagimachi [89].

ICSI has been very successful in the mouse and human [89]. It is somewhat surprising that ICSI has not been very successful in farm animals [90]. The reason for this is not clear, but it could arise from the injection of spermatozoa with "intact" or "almost intact" plasma membranes. As pointed out by Yanagimachi [89], sperm plasma membrane (of both head and tail regions) does not enter the egg during natural fertilization and therefore sperm's intracellular components (including the nucleus and centrosome) are quickly exposed to the egg cytoplasm after sperm-egg fusion. When a plasma membrane-intact spermatozoon is injected into an egg, sperm's plasma membrane might not break down or breaks down long after injection. This would prevent or delay activation of the egg and/or the development and union of the male and female prononuclei [91]. Introduction of sperm acrosome (containing various hydrolyzing enzymes) into egg cytoplasm by ICSI, which never takes place during natural fertilization, may damage the egg's cytoplasmic components including cytoskeleton system.

For successful mouse ICSI, only the sperm nucleus (with haploid genome) and the perinuclear materials (containing egg-activating factor) are necessary $[92,93]$. In human ICSI, a functional sperm centrosome must be injected with a sperm nucleus into the egg to ensure the successful union of male and female pronuclei [94. 95]. In $1990,100 \%$ of human assisted fertilization were by IVF. Today, $60-100 \%$ of human eggs in infertility clinics are inseminated by ICSI because of ICSI' s high efficiency and requests from aging patients who desperately want to have their first baby as soon as possible, even if ICSI is not necessarily the first choice of treatment.

\section{Other Assisted Fertilization Technologies}

Before the advent of human ICSI, partial zona dissection (PZD), subzona-insemination (SUZI) and gametes intra Fallopian transfer (GIFT) were used when eggs were not fertilized well by conventional IVF. As success rates of these techniques remained low [96], today's fertility clinics seldom use these techniques. However, we should be aware that GIFT is the only assisted fertilization the Vatican approves as it entails fertilization in vivo.

Human spermatozoa collected from the testis are as effective as those from semen in producing ICSI babies [97]. While some clinicians reported birth of healthy babies after injection of round spermatids into eggs (e.g. [98]), others failed to do so (e.g. [99, 100]). The American Society of Reproductive Medicine [101] recommended that round spermatid injection (ROSI) should not be performed when more mature forms (elongated spermatids or spermatozoa) are available for ICSI. It recommended clinicians to consider ROSI as experimental and that candidates for ROSI should be informed of the potential risks of the procedure.

By contrast, mouse ROSI is far more successful than human 
ROSI. Many healthy fertile mouse offspring were born after ROSI in various laboratories. Even live offspring were obtained after injection of spermatocyte nuclei $[89,102]$. The earlier the stage of spermatogenesis, the more difficult it has been to obtain live offspring. This could partly caused by epigenetic errors in the zygotes generated by the use of spermatid [103] and spermatocyte nuclei. Lack of "maturation" of the centrosome in pre-spermatozoal cells could attribute to the poor development of zygotes [104].

\section{Some Other Important Breakthroughs Associated, Directly and Indirectly, to Assisted Fertilization}

\section{Induction of superovulation}

A large South American rodent Plains Viscacha, weighing up to $9 \mathrm{~kg}$, ovulates 200-800 eggs at one time during natural estrous cycle, but only few embryos implant, and only two are usually born [105]. In most other animals only 1 to $10 \mathrm{~s}$ eggs are ovulated at one time. Many pioneers induced superovulation by injection of crude or partially purified preparations of gonadotrophins. Pincus [106], for example, obtained up to 80 eggs from a single female rabbit by consecutive injections of FSH and LH. Superovulation in adult female mice by PMSG and HCG injections, which is routinely performed today in basic studies of fertilization and embryo development was first achieved by Edwards and his associates [107, 108], for which Edwards and his associates well deserve another Nobel Prize in the author's personal opinion. The induction of superovulation in highly productive cows, insemination using frozen-thawed spermatozoa of a superior bull, and non-surgical transfer of preimplantation embryos [109] to sturdy surrogate cows, have been performed successfully in the cattle industry world-wide [110, 111].

\section{Cryopreservation of spermatozoa and eggs}

Deep-freeze preservation of mammalian eggs and spermatozoa (as well as many other types of cells) makes it possible to keep them "alive" almost indefinitely. Its contribution to basic research as well as medical and agricultural practice is immense. Jean Rostand was the first to report cryoprotective action of glycerol on frog spermatozoa, but it was Chris Polge who put glycerol into the limelight $[112,113]$. For an interesting story of the fortuitous discovery of glycerol as cryoprotectant, readers are referred to Hunter [114]. Today, most of daily and beef cattles are inseminated with freeze-thawed spermatozoa world-wide. Long-term cryopreservation of spermatozoa is also successful in a variety of animals and human. Spermatozoa of the mouse, which are commonly used for the basic study of fertilization, can be cryopreserved using raffinose as cryoprotectant [115]. Perhaps, the simplest way to cryopreserve mouse spermatozoa is to maintain the whole body of an euthanized male (or isolated testes) frozen at constant temperature of -20 C . When needed, the body or testis is defrosted, spermatozoa are retrieved, their heads (nuclei) are isolated and injected into eggs microsurgically. Spermatozoa are technically "dead", but sperm nuclei are able to produce normal offspring by ICSI even after 15 years storage of frozen bodies [116]. Cryopreservation of mammalian eggs (preimplantation embryos) first succeeded in the mouse [117]. Today, we are able to cryopreserve spermatozoa, eggs and preimplantation embryos of various mammals including the human [118-120].

\section{Sexing of spermatozoa}

The presence of X- and Y-chromosome-bearing spermatozoa in mammals has been known for a long time. Most researchers, including the author himself, thought that it would be extremely difficult or impossible to separate X-and Y- bearing spermatozoa because of very small (3 to 4\%) difference in DNA mass in their nuclei. We were wrong. Since Johnson and his associates first succeeded in separating X- and Y-rabbit spermatozoa [121], the steady improvement of the flow cytometric method [122] made it possible to sexing spermatozoa with $85-95 \%$ accuracy in various species including sheep, pig, horse, elk, cat, dog and human [123, 124]. The production of sexed frozen semen of the bull has been commercialized [125].

\section{Transgenesis and the use of gene-knockout animals}

Animal transgenesis was pioneered by Jaenisch and Mintz [126], Gordon et al. [127] and the gene knockout technology by Thomas and Capecchi $[128,129]$. These advances were truly revolutionary. Hundreds of transgenic mice have been produced for basic studies of basic biological processes as well as the production of many farm animals with desirable characteristics [130-132]. Gene knockout of laboratory animals, in particular mice, became an essential tool for our understanding the functions of genes in all biological processes including mammalian gametogenesis [133, 134] and fertilization [29, 30, 37].

\section{Future Research}

Although the most exciting discoveries are almost always unpredictable, the author dares to list several subjects that he hopes will come true.

\section{Mass production of mature gametes in vitro}

As a researcher of animal fertilization, the author sacrificed a great many animals. This must be true for almost all researchers who engage in the studies of gametes and fertilization. If we were unable to induce superovulation in the mouse, for example, we would have needed to sacrifice 3-4 times more females than we did. If we could produce unlimited number of mature eggs and spermatozoa in vitro from few primordial germ cell, embryonic stem (ES) cells or induced pluripotent (iP) cells, we would no longer have to sacrifice so many animals for gamete research alone. The production of mature eggs (mouse) from very small follicles [135] and fish (eel) spermatozoa from spermatogonia [136] is possible today. According to Stukenborg et al. [137], mouse spermatogenic cells before entering meiosis can develop in vitro to morphologically normal spermatozoa. Perhaps within several decades we should be able to mass produce fully mature eggs and spermatozoa of economically valuable animals any time of the year.

\section{Selection of genomically normal gametes and zygotes}

In animals, the birth and survival of offspring with severe abnormalities are prevented by spontaneous abortion and infanti- 
cide. Spontaneous abortions of embryos and fetuses with severe congenital abnormalities occur in humans as well. What we have to be concerned with most is the birth of children with relatively minor defects, which may or may not threaten life. As all parents who need help from assisted fertilization-like all other parents want their children to be healthier and happier than themselves, all efforts should be directed to avoid the use of genetically and epigenetically aberrant gametes for assisted fertilization. It is most unlikely that morphological, physical, and biochemical characteristics of gametes and early embryos can predict genetic normality and abnormality of offspring. Non-invasive genomic and epigenetic analyses of zygotes and early embryos would be preferable to distinguish normal and aberrant genetic status of future offspring [138]. A personal human genome analysis cost \$3 billions in 1990. This price is rapidly reducing and was down to US \$5,000 in 2009. It might even reduce to US $\$ 100$ before long. Complete genomic and epigenetic analyses would not be necessary. Even the detection of several most common genetic and epigenetic aberrations in embryos would greatly reduce the chance of the birth of adversely affected offspring. Couples in advanced age and those with high risks of transmitting aberrant genetic and epigenetic factors to their offspring would benefit most from the genetic diagnosis of preimplantation embryos [139].

\section{Sex pre-selection of spermatozoa}

For species whose spermatozoa show considerable variations in sperm head size and shape (e.g., humans), determination of DNA concentration of individual spermatozoa and insemination by ICSI would be a better method for avoiding transmission of defective Y-chromsome, for example, to offspring.

\section{Long-term preservation of spermatozoa at ambient temperature}

The use of deep freezers for sperm preservation is cumbersome. It would be ideal if we could preserve spermatozoa at ambient temperature indefinitely. Freeze-dried or vacuum-dried mouse spermatozoa can be kept (shipped) at room temperature for a few weeks without loosing their fertility (by ICSI), but not indefinitely [140]. This is true for mouse spermatozoa desiccated and stored in treahalose medium at $20 \mathrm{C}$ [141]. Tateno et al [142] found that mouse spermatozoa kept in $70 \%$ ethanol at $-20 \mathrm{C}$ for 1 day could produce live offspring by ICSI, but not after longer storages in the ethanol; sperm chromosomes were damaged extensively after long sojourn in ethanol. It could be sperm proteins, not DNA, that are damaged by ethanol. Someday, it may become possible to keep spermatozoa (or their nuclei) "alive" at ambient temperature indefinitely.

\section{Freezing of fish eggs}

The eggs with small amounts of yolk (like those of eutherian mammals) can also be kept frozen, but not those with large amount s of yolk (e.g., fish eggs). When trout eggs were frozen and defrosted, they looked fine at first, but soon all disintegrated. Egg plasma membranes seemed to be vulnerable to freeze- thawing (Yanagimachi and Sankai, unpublished data). If we can keep fish eggs and spermatozoa frozen without losing their fertility for months or years, it would not only facilitate basic research of fish fertilization, but also benefit fish breeding in hatcheries.

\section{Conversion of somatic cells to germ cells}

Since Toyooka et al. [143] and Huebner et al. [144] reported development of sperm-like and egg-like cells from mouse embryonic stem (ES), many investigators confirmed that ES cells as well as iP cells can develop into "spermatozoa" and "egg" in vivo or in vitro [145-147]. It should be noted that none of the investigators thoroughly examined the cell's meiotic processes and germ cellspecific genomic imprintings. Mere examinations of the cell's gross morphology, DNA concentration and the expression of few germ cell-specific genes are not enough to determine if the cells are really functional spermatozoa and eggs. Recent study by Hayashi et al. [148] is noteworthy. They first converted ES cells or iPS cells into primordial germ cell-like cells (PGCLCs) which was transferred into seminiferous tubules of 7-9 day old infant males. When examined 8-10 weeks later, some tubules contained spermatozoa developed from transplanted PGCLCs. These spermatozoa could produce fertile male and female offspring by ICSI. Someday, we should be able mass- produce spermatozoa and egg in vitro without using testes or ovaries. "Eggs and spermatozoa" thus produced do not need to look like ordinary eggs and spermatozoa. As long as their nuclei are truly haploid and properly imprinted, they can be used as substitutes for the nuclei of normal egg and spermatozoa. Mature eggs from donors, which nuclei have been removed, would be safe vehicles for the haploid nuclei thus produced.

\section{Transgenic animals}

ES cell-mediated transgenesis is site-specific, but it is technically cumbersome and time-consuming. Hopefully site-specific transgenesis as reported by Tasic et al. [149] move the field in the right direction of the development of a safe and efficient transgenesis in laboratory animals and economically valuable animals. As to farm animals, odor emission from livestock operations is a very serious problem to nearby residents. It certainly discourages many young fellows from entering animal-related industries. Odor of house pets is not a desirable thing for owners as well as visitors and neighbors. Elimination or at least great odor reduction from animal excretions should be attempted using gene manipulation technologies.

\section{Acknowledgements}

The author wish to thank to Dr J Cummins and Mrs C Oser for reading the original manuscript and giving me invaluable advice. He is indebted to Dr G Seidel for valuable information about sperm sexing.

\section{References}

1. Ford BJ. The Leeuwenhoeck Legacy. Bristol -London: Biopress \& Farrand Press; 1991.

2. Austin CR. The Mammalian Egg. Springfield: C.C. Thomas Pub; 1961

3. Chang MC. Fertilizing capacity of spermatozoa deposited into the Fallopian tubes. Nature 1951; 168: 697-698. [Medline] [CrossRef]

4. Austin CR. The "capacitation" of the mammalian sperm. Nature 1952; 170: 326 [Medline] [CrossRef] 
5. Noyes RW. The fertilizing capacity of spermatozoa. West J Surg 1953; 61: 342-349. [Medline]

6. Fawcett DW. A comparative view of sperm ultrastructure. Biol Reprod 1970; (Suppl 2): 90-127. [Medline] [CrossRef]

7. Cummins JM, Woodall PF. On mammalian sperm dimens ions. J Reprod Fertil 1985; 75: 153-175. [CrossRef]

8. Eddy EM. The spermatozoa. In: Neill JD (eds.), The Physiology of Reproduction. St. Louis: Elsevier Academic Press; 2006: 3-54

9. Wassarman PM, Albertini DF. The mammalian ovum. In: Knobil E, Neill JD (eds.), The Physiology of Reproduction. New York: Raven Press; 1994: 79-122.

10. Cooper GT. The Epididymis, Sperm Maturation and Fertilization. Berlin: SpringerVerlag; 1986.

11. Bedford JM. The status and the state of human epididymis. Hum Reprod 1994; 9: 2187-2199. [Medline]

12. Hinton BT, Palladino MA, Rudolph D, Lan ZJ, Labus JC. The role of the epididymis in the protection of spermatozoa. Curr Top Dev Biol 1996; 33: 61-102. [Medline] [CrossRef]

13. Harper MJK. Gamete and zygote transport. In: Knobl E, Neill JD (eds.), The Physiology of Reproduction. New York, Raven Press; 1994: 123-187.

14. Suarez SS. Gamete and zygote transport. In: Neill JD (ed.), The Physiology of Reproduction. St. Louis: Elsevier Academic Press; 2006: 113-145.

15. Bedford JM. Sperm capacitation and fertilization in mammals. Biol Reprod 1970; (Suppl 2): 128-158. [Medline] [CrossRef]

16. Yanagimachi R. Mechanism of fertilization in mammals. In: Mastroianni L, Biggers JD (eds.), Fertilization and Embryonic Development In Vitro. New York: Plenum Press; 1981: 81-182.

17. Yanagimachi R. Mammalian fertilization. In: Knobill E, Neill JD (eds.), The Physiology of Reproduction. New York: Raven Press; 1994: 189-317.

18. Visconti PE, Florman HM. Mechanism of sperm-egg interactions: between sugars and broken bonds. Sci Sygnal 2010; 5: 35

19. Bailey JL. Factors regulating sperm capacitation. Syst Biol Reprod Med 2010; 56: 334-348. [Medline] [CrossRef]

20. Breitbart H, Rubinstein S, Lax Y. Regulatory mechanisms in acrosome reaction. Rev Reprod 1997; 2: 165-174. [CrossRef]

21. Meizel S. The sperm, a neuron with a tail: 'neuronal' receptors in mammalian sperm. Biol Rev Camb Philos Soc 2004; 79: 713-732. [Medline] [CrossRef]

22. Florman HM, Jungnickel M, Sutton KA. Regulating the acrosome reaction. Int $J$ Dev Biol 2008; 52: 503-510. [Medline] [CrossRef]

23. Yanagimachi R. Mammalian sperm acrosome reaction; where does it begin before fertilization. Biol Reprod 2011; 85: 4-5. [Medline] [CrossRef]

24. Dunbar BS, O'Rand MG (eds.) A Compartive Overview of Mammalian Fertilization. New York: Plenum Press; 1991.

25. Wassarman PM (ed.) Elements of Mammalian Fertilization. Boca Raton: CRC Press; 1991.

26. Hardy DM (ed.) Fertilization. San Diego: Academic Press, 2002.

27. Florman HM, Dicibella T. Fertilization in mammals. In: Neill JD (ed.), The Physiology of Reproduction. St. Louis: Elsevier Academic Press; 2006: 55-112.

28. Toshimori K. Dynamics of the Mammalian Fertilization. Berlin: Springer-Verlag; 2009

29. Ikawa M, Inoue N, Benham AM, Okabe M. Fertilization: as sperm's journey and interaction with the oocyte. $J$ Clin Invest 2010; 120: 984-994. [Medline] [CrossRef]

30. Kim E, Yamashita M, Kimura M, Honda A, Kashiwabara S, Baba T. Sperm penetration through cumulus mass and zona pellucida. Int J Dev Biol 2008; 52: 677-682. [Medline] [CrossRef]

31. Bedford JM. Site of t he mammalian sperm physiological acrosome reaction. Proc Natl Acad Sci USA 2011; 108: 4703-4704. [Medline] [CrossRef]

32. Wassarman PM. Mammalian fertilization: molecular aspects of gamete adhesion, exocytosis, and fusion. Cell 1999; 96: 175-183. [Medline] [CrossRef]

33. Wassarman PM, Jovine L, Qi H, Williams Z, Darie C, Litscher S. Recent aspects of mammalian fertilization research. Mol Cell Endocrinol 2005; 234: 95-103. [Medline] [CrossRef]

34. Dean J. The enigma of sperm-egg interaction in mice. Soc Reprod Fert Suppl 2007; 63: 359-365.

35. Bedford JM. Puzzles of mammalian fertilization- and beyond. Int J Dev Biol 2008; 52: 415-426. [Medline] [CrossRef]

36. Yanagimachi R. Sperm-egg fusion. Curr Topics Memb Transp 1988; 32: 3-43.

37. Ikawa M, Inoue N, Okabe M. Machanimsms of sperm-egg interactions emerging from gene-manipulated animals. Int J Dev Biol 2008; 52: 657-664. [Medline] [CrossRef]

38. Miyazaki S, Ito M. Calcium signals for egg activation in mammals. J Pharmacol Sci 2006; 100: 545-552. [Medline] [CrossRef]

39. Swann K, Yu Y. The dynamics of calcium oscillations that activate mammalian eggs.
Int J Dev Biol 2008; 52: 585-594. [Medline] [CrossRef]

40. Schatten G. The centrosome and its mode of inheritance: the reduction of the centrosome during gametogenesis and its restoration during fertilization. Dev Biol 1994 165: 299-335. [Medline] [CrossRef]

41. Schatten H. The mammalian centrosome and its functional significance. Histochem Cell Biol 2008; 129: 667-686. [Medline] [CrossRef]

42. Shenk SL. Das Saeugethierei kunstrich befruchtet ausserhalb des Mutterthieres. Mitt Embryo Inst $K$ K Wien 1878; 1: 107-118.

43. Pincus G, Enzmann EV. Can mammalian eggs undergo normal development in vitro? Proc Natl Acad Sci USA 1934; 20: 121-122. [Medline] [CrossRef]

44. Venge O. Experiments on fertilization of rabbit ova in vitro with subsequent transfer to alien does. In: Wolstenholm GEW, Cameron MP, Freeman JS (eds.), Mammalin Germ Cells. London: Churchill; 1953.

45. Thibault C, Dauzier L, Winterberger S. Etude cytologoque de la fecundation in vitro de l'oeuf de la lapin. C R Soc Biol Anim Biochem Biphys 1954; 148: 789-790.

46. Chang MC. Fertilization of rabbit ova in vitro. Nature 1959; 184: 466-467. [Medline] [CrossRef]

47. Brackett BG, Oliphant G. Capacitation of rabbit spermatozoa in vitro. Biol Reprod 1975; 12: 260-274. [Medline] [CrossRef]

48. Zeng SM, Zhu E, Wang YS, Chen XJ, et al An efficient method for in vitro fertilization in rabbit. Anim Biotech 1999; 10: 15-23. [CrossRef]

49. Mrsny RJ, Waxaman L, Meizel S. Taurine maintains and stimulates motility of hamster sperm during capacitation in vitro. J Exp Zool 1979; 210: 123-128. [Medline] [CrossRef]

50. Leibfried ML, Bavister BD. Effects of epinephrine and hypotaurine on in vitro fertilization in the golden hamster. J Reprod Fertil 1982; 66: 87-93. [Medline] [CrossRef]

51. Yanagimachi R. In vitro sperm capacitation and fertilization of golden hamster eggs in a chemically defined medium. In: Hafez ESE, Semm K (eds.), In Vitro Fertilization and Embryo Transfer. Lancaster: MTP Press; 1982.

52. Guerin $\mathbf{P}$, Menezo $\mathbf{Y}$. Hypotaurine and taurine in gamete and embryo environments: de novo synthesis via the cystein sulfinic acid pathway in oviduct cells. Zygote 1995; 3: 333-343. [Medline] [CrossRef]

53. Menkin MF, Rock J. In vitro fertilization and cleavage of human ovarian eggs. Am J Obstet Gynecol 1948; 55: 440-452. [Medline]

54. Shettles LBA. A morula stage of human ovum developed in vitro. Fertil Steril 1955 6: 287-289. [Medline]

55. Steptoe PC, Edwards RG. Birth after the reimplantation of human embryo. Lance 1978; 2(8085): 366. [Medline] [CrossRef]

56. Trounson AO, Wood C. IVF and related technology. The present and the future. Med J Aust 1993; 158: 853-857. [Medline]

57. Menezo YJ, Veiga A, Pouly JL. Assisted reproductive technology (ART) in humans: facts and uncertainties. Theriogenology 2000; 53: 599-610. [Medline] [CrossRef]

58. Edwards RG. The bumpy road to human in vitro fertilization. Nature Med 2001; 7 1091-1094. [Medline] [CrossRef]

59. Uehara T, Yanagimachi R. Microsurgical injection of spermatozoa into hamster eggs with subsequent transformation of sperm nuclei into male pronuclei. Biol Reprod 1976; 15: 467-470. [Medline] [CrossRef]

60. Uehara T, Yanagimachi R. Behavior of nuclei of testicular, caput and cauda epididymal spermatozoa injected into hamster eggs. Biol Reprod 1977; 16: 315-321. [Medline] [CrossRef]

61. Naish SJ, Perreault SD, Zirkin BR. DNA synthesis following microinjection of heterologous sperm and somatic cell nuclei into hamster oocytes. Gamete Res 1987; 18 109-120. [Medline] [CrossRef]

62. Perreault SD, Barbee RR, Elstein KH, Zucker RR, Keefer CL. Interspecies differences in the stability of mammalian sperm nuclei assessed in vivo by sperm microinjection and in vitro by flow cytometry. Biol Reprod 1988; 39: 157-167. [Medline] [CrossRef]

63. Iritani A, Hoshi Y. Microfertilzation by various methods in mammalian species. Prog Clin Biol Res 1989; 294: 145-149. [Medline]

64. Goto K, Kinoshita A, Tamura Y, Ogawa K. Fertilization of bovine oocytes by the injection of immobilized, killed spermatozoa. Vet Res 1990; 127: 517-520.

65. Palermo G, Joris H, Devroey P, van Steirteghem AC. Pregnancies after intracytoplasmic injection of a single spermatozoon into an oocyte. Lancet 1992; 340: 17-18 [Medline] [CrossRef]

66. Mukherjee AB, Cohen MM. Development of normal mice by in vitro fertilization Nature 1970; 228: 472-473. [Medline] [CrossRef]

67. Toyoda Y, Chang MC. Fertilization of rat eggs in vitro by epididymal spermatozo and the development of eggs following transfer. J Reprod Fertil 1974; 36: 9-22. [Medline] [CrossRef]

68. Barnett DK, Bavister BD. Hypotaurine requirement for in vitro development of golden hamster one-cell embryos into morulae and blastocysts, and production of 
term offspring from in vitro-fertilized ova. Biol Reprod 1992; 47: 297-304. [Medline] [CrossRef]

69. Goodrowe KL, Wall RJ, O'Brien SJ, Schmidt PM, Wildt DE. Developmental competence of domestic cat follicular oocytes after fertilization in vitro. Biol Reprod 1988; 39: 355-372. [Medline] [CrossRef]

70. Palmer E, Bezard J, Migistrini M, Duchamp G. In vitro fertilization in the horse: a retrospective study. J Reprod Fertil 1991; (Suppl 44): 375-384. [Medline]

71. Brackett BG, Bousquet D, Boice ML, Donawick WJ, Evans JF, Dressel MA. Normal development following in vitro fertilization in the cow. Biol Reprod 1982; 27: 147-158. [Medline] [CrossRef]

72. Nagai T, Takahashi T, Masuda H, Shioya Y, Kuwayama M, Fukushima M, Iwasaki S, Hanada A. In-vitro fertilization of pig oocytes by frozen boar spermatozoa. $J$ Reprod Fertil 1988; 84: 585-591. [Medline] [CrossRef]

73. Clayton N, Huneau D, Desmedt V, Théron MC, Szöllös D, Torrès S, Sèvellec C. In vitro fertilization with normal development in the sheep. Gamete Res 1987; 16: 159-170. [Medline] [CrossRef]

74. Hanada A. In vitro fertilization in goat. Jpn J Anim Reprod 1985; 31: 21-26.

75. Clayton O, Kuehl TJ. The first successful in vitro fertilization and embryo transfer in a nonhuman primate. Theriogenol 1984; 21: 228. [CrossRef]

76. Bavister BD, Boatman DE, Collins K, Dierschke DJ, Eisele SG. Birth of rhesus monkey infant after in vitro fertilization and nonsurgical embryo transfer. Proc Natl Acad Sci USA 1984; 81: 2218-2222. [Medline] [CrossRef]

77. Balmaceda JP, Pool TB, Arana JB, et al. Successful in vitro fertilization and embryo transfer in cynomolgus monkeys. Fert Steril 1984; 42: 791-795. [Medline]

78. Kimura Y, Yanagimachi R. Intracytoplasmic sperm injection in the mouse. Biol Reprod 1995; 52: 709-720. [Medline] [CrossRef]

79. Miyata T, Okada H, Hashizume R, et al The offspring of intracytoplasmic sperm injection in the rat. J Mamm Ova Res 2000; 17: 5-24.

80. Yamauchi Y, Yanagimachi R, Horiuchi T. Full-term development of golden hamster oocytes following intracytoplasmic sperm injection. Biol Reprod 2001; 67: 534 539. [CrossRef]

81. Pope CE, Johnson CA, McRae MA, Keller GL, Dresser BL. Development of embryos produced by intracytoplasmic sperm injection of cat oocytes. Anim Reprod Sci 1998; 53: 221-226. [Medline] [CrossRef]

82. Cochran R, Meintjes M, Roggio B, Hylan D, Carter J, Pinto C, Paccamonti D, Godke RA. Live foals produced from sperm-injected oocytes derived from pregnant mares. J Equine Vet Sci 1998; 18: 736-740. [CrossRef]

83. Kolbe T, Holtz W. Birth of a piglet derived from an oocyte fertilized by intracytoplasmic sperm injection. Anim Reprod Sci 2000; 64: 97-101. [Medline] [CrossRef]

84. Catt SL, Catt W, Gomez C, Maxwell WMC, Evans G. Birth of male lamb derived from an in vitro mature oocyte fertilized by intracytoplasmic injection of a single presumptive male sperm. Vet Rec 1996; 139: 494-495. [Medline] [CrossRef]

85. Wang B, Baldassarrel H, Pierson J, Cote F, Rao KM, Karatzas CN. The in vitro and in vivo development of goat embryos produced by injection using tail-cut spermatozoa. Zygote 2003; 11: 219-227. [Medline] [CrossRef]

86. Simerly CR, Castro CA, Jacoby E, Grund K, Turpin J, McFarland D, Champagne J, Jimenez JB, Frost P, Bauer C, Hewitson L, Schatten G. Assisted reproductive technologies (ART) with baboons generate live offspring: a nonhuman primates model for ART and reproductive sciences. Reprod Sci 2010; 17: 917-930. [Medline] [CrossRef]

87. Hewitson L, Martinovich C, Simerly C, Takahashi D, Schatten G. Rhesus offspring produced by intracytoplasmic sperm injection of testicular sperm and elongated spermatids. Fert Steril 2002; 77: 794-801. [Medline] [CrossRef]

88. Ng SC, Liow SL, Herbert S, Oh SH. Intracytoplasmic injection of frozen-thawed spermatozoa in a nonhuman primate model, the cynomolgus monkey (Macaca fascicularis). Theriogenology 2002; 58: 1385-1397. [Medline] [CrossRef]

89. Yanagimachi R. Intracytoplasmic injection of spermatozoa and spermatogenic cells: its biology and applications in human and animals. Reprod BioMed Online 2005; 10: 247-288. [Medline] [CrossRef]

90. Garcia-Rosello E, Garcia-Menqual E, Coy P, Alfonso J, Silvestre MA. Intracytoplasmic sperm injection in livestock species: an update. Reprod Domest Anim 2009; 44: 143-151. [Medline] [CrossRef]

91. Morozumi K, Shikano T, Miyazaki S, Yanagimachi R. Simultaneous removal of sperm plasma membrane and acrosome before intracytoplasmic sperm injection improves oocyte activation/embryonic development. Proc Natl Acad Sci USA 2006; 103: 17661-17666. [Medline] [CrossRef]

92. Kuretake S, Kimura Y, Yanagimachi R. Fertilization and development of mouse oocytes injected with isolated sperm heads. Biol Reprod 1996; 55: 789-795. [Medline] [CrossRef]

93. Kimura Y, Yanagimachi R, Kuretake S, Bortkiewicz H, Perry AC, Yanagimachi H. Analysis of mouse oocyte activation suggests the involvement of sperm perinuclear material. Biol Reprod 1998; 58: 1407-1415. [Medline] [CrossRef]
94. Palermo GD, Colombero LY, Rosenwaks Z. The human sperm centrosome is responsible for normal syngamy and early embryonic development. Rev Reprod 1997; 2: 19-27. [Medline] [CrossRef]

95. Terada Y, Schatten G, Hasegawa H, Yaegashi N. Essential roles of the sperm centrosome in human fertilization: developing the therapy for fertilization failure due to sperm centrosome dysfunction. Tohoku J Exp Med 2010; 220: 247-258. [Medline] [CrossRef]

96. Van Rumste MM, Evers JL, Farquhar CM, Blake DA. Intra-cytoplasmic sperm injection versus partial zona dissection, subzonal insemination and conventional technique for oocyte insemination during in vitro fertilization. Cochrane Database Syst Rev 2000; 2: CD001301. [Medline]

97. Devroey P, Nagy P, Tournaye H, Liu J, Silber S, Van Steirteghem A. Outcome of intracytoplasmic sperm injection with testicular spermatozoa in obstructive and nonobstructive azoospermia. Hum Reprod 1996; 11: 1015-1018. [Medline]

98. Barak Y, Kogosowski A, Goldman S, Soffer Y, Gonen Y, Tesarik J. Pregnancy and birth after transfer of embryos that developed from single nucleated zygotes obtained by injection of round spermatids into oocytes. Fert Steril 1998; 70: 67-70. [Medline] [CrossRef]

99. Yamanaka K, Sofikitis NV, Miyagawa I, Mekras G, Mio Y, Toda T, Antypas S, Kawamura H, Kanakas N, Antoniou N, Loutradis D, Mantzavinos T, Kalianidis K, Agapitos E. Ooplasmic round spermatid nuclear injection procedures as an experimental treatment of non-obstructive azoospermia. J Assist Repod Genet 1997; 14 55-62. [CrossRef]

100. Urman B, Alatas C, Aksoy S, Mercan R, Nuhoglu A, Mumcu A, Isiklar A, Bala ban $\mathbf{B}$. Transfer at the blastocyst stage of embryos derived from testicular spermatid injection. Hum Reprod 2002; 17: 741-743. [Medline] [CrossRef]

101. American Society for Reproductive Medicine. Fert Steril 2003; 80: 687-689. [CrossRef]

102. Ogura A, Ogonuki H, Inoue K. Microinsemination and nuclear transfer using male germ cells. Int Rev Cytol 2005; 246: 189-229. [Medline] [CrossRef]

103. Kishigami S, Van Thuan N, Hikich I, Ohta H, Wakayama S, Mizutani E, Wakayama T. Epigenetic abnormalities of mouse paternal zygotic genome associated with microinsemination of round spermatids. Dev Biol 2006; 289: 195-205. [Medline] [CrossRef]

104. Tachibana M, Terada Y, Ogonuki N, Ugajin T, Ogura A, Murakami T, Yaegashi N, Okamura K. Functional assessment of centrosomes of spermatozoa and spermatid microinjected into rabbit oocytes. Mol Reprod Dev 2009; 76: 270-277. [Medline] [CrossRef]

105. Weir BJ. The reproductive organs of the female plains viscacha, Lagostomus maxi mus. J Reprod Fertil 1971; 25: 365-373. [Medline] [CrossRef]

106. Pincus G. Superovulation in rabbits. Anat Rec 1940; 77: 1-8. [CrossRef]

107. Fowler RE, Edwards RG. Induction of superovuation and pregnancy in mature mice by gonadotropins. J Endocrinol 1957; 15: 374-384. [Medline] [CrossRef]

108. Edwards RG, Gates AH. Timing of the stages of the maturation divisions, ovulation, fertilization and the first cleavage of eggs of adult mice treated with gonadotrophins. J Endocrinol 1959; 18: 292-304. [Medline] [CrossRef]

109. Sugie T. Successful transfer of a fertilized bovine egg by non-surgical techniques. $J$ Reprod Fertil 1965; 10: 197-201. [Medline] [CrossRef]

110. Seidel GE. Superovulation and embryo transfer in cattle. Science 1981; 211: 351-358 [Medline] [CrossRef]

111. Bo GA, Guerrero DC, Tribulo A, Tribulo H, Tribulo R, Rogan D, Mapletoft RJ. New approaches to superovulation in the cow. Reprod Fertil Dev 2010; 22: 106-112. [Medline] [CrossRef]

112. Polge C, Smith AU, Parkes AS. Revival of spermatozoa after vetrifiation and dehydration at low temperature. Nature 1949; 164: 666-669. [Medline] [CrossRef]

113. Polge C, Rowson LEA. Long term storage of bull semen frozen at very low temperature. Proc $2^{\text {nd }}$ Int Congr Anim Reprod Copenhagen 1952; 3: 90-98.

114. Hunter RHF, Ernst J. Christopher Polge. Biogr Mem Fell Roy Soc 2008; 54: 275 296.

115. Nakagata N. Cryopreservation of mouse spermatozoa and in vitro fertilization. In: Hofker MH, van Deursen JM (eds.), Methods in Molecular Biology. New York; Humana Press; 2011: 693: 7-73.

116. Ogonuki N, Mochida K, Miki H, Inoue K, Fray M, Iwaki T, Moriwaki K, Obata Y, Morozumi K, Yanagimachi R, Ogura A. Spermatozoa and spermatids retrieved from frozen reproductive organs or frozen whole bodies of male mice can produce normal offspring. Proc Natl Acad Sci USA 2006; 103: 13098-13103. [Medline] [CrossRef]

117. Whittingham DG. Fertilization in vitro and development of unfertilized mouse oocytes previously stored at -196 degree C. J Reprod Fertil 1977; 49: 89-94. [CrossRef]

118. Porcu E, Venturoli S. Progress with oocyte cryopreservation. Curr Opin Obstet Gynecol 2006; 18: 273-279. [Medline] [CrossRef]

119. Barbas JP, Mascarenhas RD. Cryopreservation of domestic animal sperm cells 
Cell Tissue Bank 2009; 10: 49-62. [Medline] [CrossRef]

120. Saragusty J, Arav A. Current progress in oocyte and embryo cryopreservation by slow freezing and vitrification. Reproduction 2011; 141: 1-19. [Medline] [CrossRef]

121. Johnson LA, Flook JP, Hawk HW. Sex preselection in rabbit: live births from Xand Y-sperm separated by DNA and cell sorting. Biol Reprod 1989; 41: 199-203. [Medline] [CrossRef]

122. Johnson LA, Welch GR, Rens W. The Beltsville sperm sexing technology: highspeed sorting gives improved sperm output for in vitro fertilization and AI. J Anim Sci 1999; 77(Suppl 2): 213-220. [Medline]

123. Seidel G. Overview of sexing sperm. Theriogenol 2007; 68: 443-446. [Medline] [CrossRef]

124. Garner DL, Seidel G. History of commercializing sexed semen for cattle. Theriogenol 2008; 69: 886-895. [CrossRef]

125. Seidel GE. Sperm sexing technology-the transition of commercial application. Theriogenol 2009; 71: 1-3. [Medline] [CrossRef]

126. Jaenisch R, Mintz B. Siminan virus 40 DNA sequences in DNA of healthy adult mice derived from preimplantation blastocysts injected with viral DNA. Proc Natle Acad Sci USA 1974; 71: 1250-1254. [CrossRef]

127. Gordon JW, Scangos GA, Plotkin DJ, Barbosa JA, Ruddle FH. Genetic transformation of mouse embryos by microinjection of purified DNA. Proc Natl Acad Sci USA 1980; 77: 7380-7384. [Medline] [CrossRef]

128. Thomas KR, Capecchi MR. Targeting of genes to specific sites in mammalian genome. Cold Spring Harbor Symp Quant Biol 1986; 51(pt 2): 1101-1113. [Medline]

129. Thomas KR, Capecchi MR. Site-sp directed mutagenesis by gene targeting in mouse embryo-derived stem cells. Cell 1987; 51: 503-512. [Medline] [CrossRef]

130. Robl JM, Wang Z, Kasinathan $\mathbf{P}$, Kuroiwa Y. Transgenic animal production and animal biotechnology. Theriogenol 2007; 67: 127-133. [Medline] [CrossRef]

131. Niemann H, Kues WA. Transgenic farm animals: an update. Reprod Fertil Dev 2007; 19: 762-790. [CrossRef]

132. Whitelaw CB, Lillico SG, King T. Production of transgenic farm animals by viral vector-mediated gene transfer. Reprod Dom Anim 2008; 43(Suppl 2): 355-358. [Medline] [CrossRef]

133. Eddy EM. Male germ cell gene expression. Recent Prog Horm Res 2002; 57: $103-$ 128. [Medline] [CrossRef]

134. Lin YN, Matzuk MM. High-throughput discovery of germ cell-specific genes. Semin Reprod Med 2005; 23: 201-212. [Medline] [CrossRef]

135. O'Brien MJ, Pendola JK, Eppig JJ. A revised protocol for in vitro development of mouse oocytes from primordial follicles dramatically improves their developmental potencies. Biol Reprod 2003; 68: 1682-1686. [Medline] [CrossRef]
136. Miura T, Yamauchi K, Takahashi H, Nagahama Y. Hormonal induction of all stages of spermatogenesis in vitro in the male Japanese eel (Anguilla japonica). Proc Natl Acad Sci USA 1991; 88: 5774-5778. [Medline] [CrossRef]

137. Stukenborg J, Schlatt S, Simoni M, Yeung CH, Elhija MA, Luetjens CM, Huleihel M, Wistuba J. New horizons for in vitro spermatogenesis? An update on novel, three-dimensional culture systems as tools for meiotic and post-meiotic differentiation of testicular germ cells. Mol Hum Reprod 2009; 15: 521-529. [Medline] [CrossRef]

138. Yanagimachi R. Problems of sperm fertility: a reproductive biologist's view. Syst Biol Reprod Med 2011; 57: 102-114. [Medline] [CrossRef]

139. Basille C, Frydman R, El Alv A, Hesters L, Fanchin R, Tachdjian G, Steffann J, LeLore'h M, Achour-Frydman N. Preimplantation genetic diagnosis: state of the art. Eur J Obstet Gynecol 2009; 145: 9-13. [Medline] [CrossRef]

140. Wakayama T, Yanagimachi R. Development of normal mice from oocytes injected with freeze-dried spermatozoa. Nat Biotech 1998; 16: 639-641. [Medline] [CrossRef]

141. McGinnis LK, Zhu L, Lawitt JA, Bhowmick S, Toner M, Biggers JD. Mouse sperm desiccated and stored in trehalose medium without freezing. Biol Reprod 2005; 73: 627-633. [Medline] [CrossRef]

142. Tateno H, Wakayama T, Ward WS, Yanagimachi R. Can alcohol retain the reproductive and genetic potential of sperm nuclei? Chromosome analysis of mouse spermatozoa in alcohol. Zygote 1998; 6: 233-238. [Medline] [CrossRef]

143. Toyooka Y, Tsunekawa N, Akasu N, Noce T. Embryonic stem cells can form germ cells in vitro. Proc Natl Acad Sci USA 2003; 100: 11457-11462. [Medline] [CrossRef]

144. Huebner K, Fuhrmann G, Christenson LK, Kehler J, Reinbold R, De La Fuente R, Wood J, Strauss III JF, Boiani M, Schueler HR. Derivation of oocytes from mouse embryonic stem cells. Science 2003; 300: 1251-1256. [Medline] [CrossRef]

145. Nagano MC. In vitro gamete derivation from pluripotent stem cells: progress and perspective. Biol Reprod 2007; 76: 546-551. [Medline] [CrossRef]

146. Chuva de Sousa Lopes SM, Roelen BA. On the formation of germ cells: the good, the bad and ugly. Differentiation 2010; 79: 131-140. [Medline] [CrossRef]

147. Ko K, Huebner K, Mueller-Keuker J, Schoeler HR. In vitro derivation of germ cells from embryonic stem cells. Front Biosci 2010; 15: 46-56. [Medline] [CrossRef]

148. Hayashi K, Ohta H, Kurimoto K, Aramaki S, Saitou M. Reconsitution of the mouse germ cell specification pathway in culture by pluripotent stem cells. Cell 2011; 146: 519-532. [CrossRef]

149. Tasic B, Hippenmeyer S, Wang C, Gamboa M, Zong H, Chen-Tsai Y, Luo L. Sitespecific integrase-mediated transgenesis in mice via pronuclear injection. Proc Natl Acad Sci USA 2011; 108: 7902-7907. [Medline] [CrossRef] 